\title{
Numerical Simulation for Shaping Feature of Molten Pool in Twin-Arc Submerged Arc Welding
}

\author{
Kuanfang He*, Jun Chen, Siwen Xiao \\ Hunan Provincial Key Laboratory of Health Maintenance for Mechanical Equipment, Hunan University of \\ Science and Technology, Xiantan, China \\ Email: *hkf791113@163.com
}

Received January 4, 2012; revised February 6, 2012; accepted February 18, 2012

\begin{abstract}
The notion of ratio of width to length is proposed to describe the shaping feature of molten pool of twin-Arc submerged arc welding accurately, and analyze the law of molten pool variation and weld formation. The temperature field finite element numerical simulation model of twin arc movement is established. The loading form of twin-arc with double ellipsoid heat source is discussed. The molten pool temperature field of twin-arc submerged arc welding is calculated and analyzed under different process parameters. The law of molten pool characteristics influenced by the welding speed, current and voltage of twin-arc submerged arc welding parameters is analyzed. The relation between shaping feature of molten pool and weld formation is discussed according to the ratio of width to length. The results manifested that the width to length ratio of weld pool decreases with the improvement of welding speed, which result in generation of weld defects. The width to length ratio of weld pool is increased by adjusting the proportion of the current, voltage and the distance of the two arcs, which avoids the generation of weld defects.
\end{abstract}

Keywords: Twin-Arc Submerged Arc Welding; Shaping Feature; Ratio of Width to Length; Numerical Simulation

\section{Introduction}

Twin-arc submerged arc welding technology is very complex, especially the heat characteristics is substantially different, so it affects the shaping feature of molten pool $[1,2]$. In the process of twin-arc submerged arc welding, technological parameters are absolutely critical for the molten pool forming, which directly affect the heat, momentum and quality of the molten pool, and has a further decision on weld formation. As a result, it is significant for the studies on the mechanism of weld formation to research the molten pool morphological characters of twinarc submerged arc welding under different technological parameters. With the development of computer technology, numerical simulation is a powerful method to obtain quantitative understanding of welding process. The numerical simulation of molten pool temperature field is an important method to research the mechanism of weld formation $[3,4]$. So it will provide essential data and theoretical foundation for the optimization and digital control of welding process.

Among the studies on loading form of arc with heat source, first, an analytic model was most usually used as point or line and face heat source was proposed [5]. The point heat source was put forward initially to simulate surface melt in welding process [6]. The units treated as

\footnotetext{
${ }^{*}$ Corresponding author.
}

heat source in melting zone was used to design calculation program of welding heat transfer, difference method was adopted in the program considering relationship between material physical property and temperature [7]. On this basis, a Gaussian distribution mathematical model for weld heat source in space was presented, then other models based on Gaussion distribution such as hemispherical distribution, ellipsoidal distribution, double ellipsoidal distribution were used to calculate the temperature field $[8,9]$. These heat sources mentioned above have been applied in temperature field numerical simulation of various welding situation. Recently, based on the double ellipsoid heat source model, a heat source model for twinwire welding was proposed [10], which was adopted to do our work in this paper.

Recently, numerical simulation on welding had been carried out. Dong et al. [11] have proposed the numerical analysis of welding residual stress for the multi-pass weldment, this paper investigates the two moving source of ramp and double-ellipsoid in prediction of residual stresses in a multi-pass-welded plate. In order to master law of molten pool variation and weld formation, numerical simulation of the molten pool temperature field had been performed by finite element method.

A transient numerical model was established to provide detailed insight about the nature of heat transfer and fluid flow during laser hybrid stationary spot welding alumi- 
num alloy [12]. The dynamic development of weld pool geometry during TIG welding was analyzed numerically, and the effect of arc moving on the weld pool geometry was discussed [13]. Deep penetration laser welding temperature field of 5A06 aluminum alloy canister structure was simulated using the surface body combination heat source model by ANSYS, which was made up of Gauss surface heat source model and Gauss revolved body heat source model, radiation and conduction were all considered during the simulation process [14]. Aval et al. [15] studied the theoretical and experimental of microstructures and weld pool geometry during GTAW of 304 stainless steel, temperature field and weld pool geometry during gas tungsten arc welding of 304 stainless steel were predicted by solving the governing equations of heat transfer and fluid flow under quasi-steady state conditions. Their research focus on the analysis of the shaping feature of molten pool and the weld formation influenced by process parameters. Taking into account the multi-field coupling, the molten pool temperature field affected by magnetic and other arc has been studied. Lin et al. [16] has introduced the multicoupled analysis function of ANSYS to analyze a moving gas tungsten arc weld pool with an external longitudinal magnetic field applied, the distributions of current density and magnetic field, as well as fluid flow and heat transfer in a moving weld pool, were systematically studied and investigated to understand and reveal the effect of an external longitudinal magnetic field on liquid metal in a moving GTA weld pool. Zhu et al. [17] analyzed the projection welding on auto-body sheet metal using a coupled finite element method. A comprehensive finite element method employing a subroutine to link up submodules of commercial code ANSYS was proposed to perform analysis of projection welding in quantitative detail. At present, based on analysis of submerged arc welding arc heat source model and droplet heat inputting uniform distribution, ANSYS parametric design language was applied to develop sub-program for three-dimensional temperature field numerical simulation of twin-arc high- speed submerged arc welding process [18].

Based on the previous research, the notion of ratio of width to length was proposed to describe the shaping feature of molten pool of twin-Arc submerged arc welding. We analyzed the law of molten pool variation and weld formation. The temperature field finite element numerical simulation model of twin arc movement was established in Section 2. Section 3 calculated the molten pool temperature field of twin-arc submerged arc welding under different technological parameters, and analyzed the law of molten pool characteristics influenced by the welding speed, current and voltage of twin-arc submerged arc welding parameters. According to the ratio of width to length, the relation between shaping feature of molten pool and weld formation were further discussed in Section 4. The conclusions were summarized in Section 5.

\section{Numerical Simulation Modeling}

Sketch of practical model was shown in Figure 1. Resurfacing welding of medium plate surface was employed to do simulation analysis, material of weldment was lowcarbon steel Q235, physical dimension of the workpiece was $200 \mathrm{~mm} \times 100 \mathrm{~mm} \times 20 \mathrm{~mm}$, and weld seam was located on center line of $x-y$ plane of the weldment. Arc center moves along the $y$ axis. Thermal physical performance parameters were thermal coefficient $\left(\mathrm{W} / \mathrm{m} \cdot{ }^{\circ} \mathrm{C}\right)$, coefficient of heat transfer $\left(\mathrm{W} / \mathrm{m}^{2} \cdot{ }^{\circ} \mathrm{C}\right)$, density $\left(\mathrm{Kg} / \mathrm{m}^{3}\right)$, specific heat $\left(\mathrm{J} / \mathrm{Kg} \cdot{ }^{\circ} \mathrm{C}\right)$, melting point $\left({ }^{\circ} \mathrm{C}\right)$ and initial temperature of workpiece $\left({ }^{\circ} \mathrm{C}\right)$. In this paper, initial temperature of workpiece was room temperature of $20^{\circ} \mathrm{C}$. The material was isotropical and change with temperature range, each thermal physical performance parameters was calculated according to the following temperature function [19]: thermal coefficient: $\lambda=54.3-0.000042 \cdot T^{2}$,

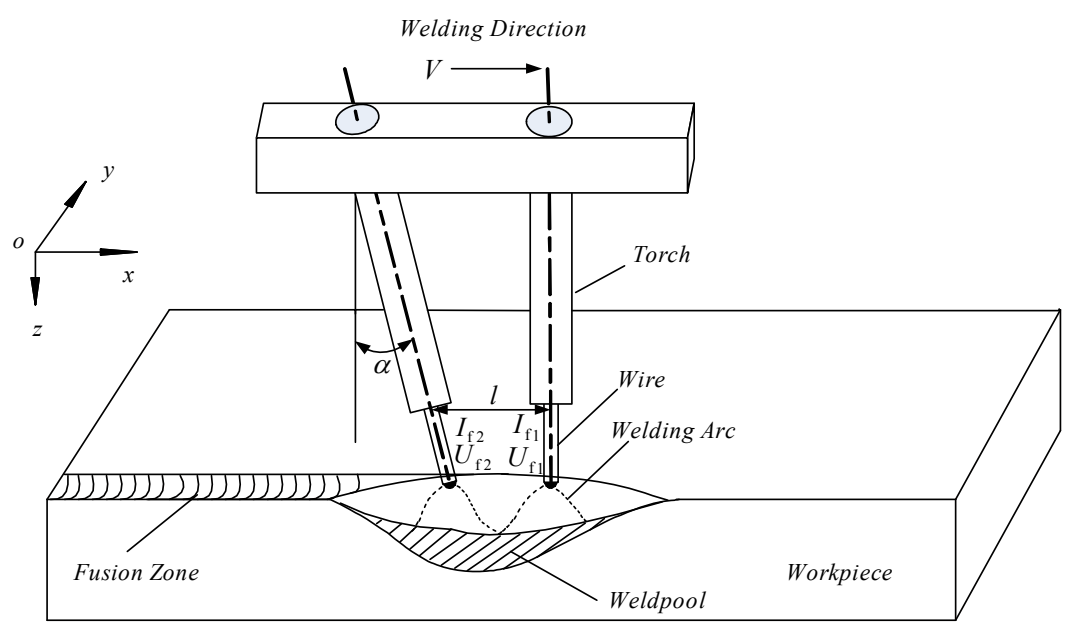

Figure 1. Sketch of practical model. 
specific heat: $\lambda=410+0.63 \cdot T^{2}$, density: $\rho=7800-0.2625 \cdot T$, coefficient of heat transfer:

$\alpha=33.5$. Interpolation was conducted on thermal physical performance parameters in the unknown temperature range [20].

\subsection{Finite Element Model and Meshing}

The three-dimensional eight-node element, SOLID70, was employed as the finite element in the generation of finite element model. Division density of elements were associated with the calculation, if the mesh was too coarse, the results probably contain serious errors, the higher the element density was, the more accurate the results was, but if the mesh was too fine, it will cost too much computing time and waste computer resources. As a result, fine mesh was used in meshing of the welding seam to obtain a higher element density and assure the computing accurate. Coarse mesh was employed in the places far away from the welding heat source, because the temperature gradient was small. So it can reconcile both computing accurate and speed. The meshing of finite element model shows as Figure 2. In addition, because of the geometrical shape and load distribution were symmetrical along the center of welding line, half of the model was computed in order to save computing time.

\subsection{Boundary Conditions}

Analysis of welding temperature field was a typical problem of non-transient heat conduction, the three-dimensional temperature field controlling equation could be given as:

$$
\rho c \frac{\partial T}{\partial t}=\frac{\partial}{\partial x}\left(\lambda \frac{\partial T}{\partial x}\right)+\frac{\partial}{\partial y}\left(\lambda \frac{\partial T}{\partial y}\right)+\frac{\partial}{\partial z}\left(\lambda \frac{\partial T}{\partial z}\right)+Q
$$

where $Q(x, y, z, t)$ is internal heat source intensity in solving domain $V, T$ is function of temperature field distribution, $\lambda$ is thermal coefficient, $\rho$ is density and $c$ is specific heat of the material. The expression above is a universal definite equation, in order to obtain certain solution, conditions of determining solution were needed, that were boundary conditions and initial conditions of differential equation. The calculations of welding temperature field often have these boundary conditions:

1) The first boundary condition, boundary temperature is given as:

$$
\lambda \frac{\partial T}{\partial x} n_{x}+\lambda \frac{\partial T}{\partial y} n_{y}+\lambda \frac{\partial T}{\partial z} n_{z}=T_{s}(x, y, z, t)
$$

2) The second boundary condition, heat flux density distribution was given as:

$$
\lambda \frac{\partial T}{\partial x} n_{x}+\lambda \frac{\partial T}{\partial y} n_{y}+\lambda \frac{\partial T}{\partial z} n_{z}=q_{x}(x, y, z, t)
$$

3) The third boundary condition, heat exchange between boundary objects and ambient medium was given as:

$$
\lambda \frac{\partial T}{\partial x} n_{x}+\lambda \frac{\partial T}{\partial y} n_{y}+\lambda \frac{\partial T}{\partial z} n_{z}=\beta\left(T_{\alpha}-T_{s}\right)
$$

In expressions (2), (3) and (4), $q_{x}$ is external heat input per unit area, $\beta$ is the surface heat transfer coefficient, $T_{\alpha}$ is the surface temperature, $T_{s}$ is ambient medium temperature, $n_{x}, n_{y}, n_{z}$ is direction cosine of external normal line respectively.

\subsection{Heat Source Model}

Gaussian heat flux distribution function was commonly used in arc welding temperature field simulation currently, which was applicable to situations of small specification and arc momentum effect, such as manual arc welding and argon tungsten-arc welding [6]. In submerged arc welding process, the specification was relatively large, it was a welding method of large arc momentum effect, and the double ellipsoidal heat source distribution function was more suitable than the Gaussian heat flux distribution function in numerical simulation of temperature. Heat of

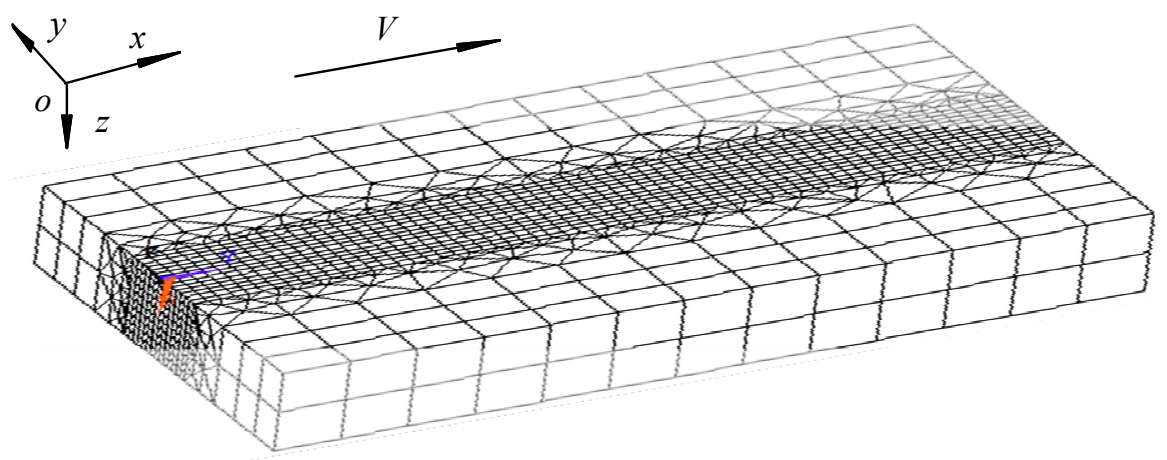

Figure 2. Finite element griddling. 
the model was mainly concentrated in the double ellipsoid above the workpiece, the mathematical expression of double ellipsoid heat source model of a moving single-arc heat source could be given as:

$$
q(x, y, z)= \begin{cases}\frac{6 \sqrt{3} f_{f} Q}{\pi \sqrt{\pi} a b_{1} c} \exp \left(-\frac{3 x^{2}}{b_{1}^{2}}-\frac{3 y^{2}}{a^{2}}-\frac{3 z^{2}}{c^{2}}\right) & x \geq 0 \\ \frac{6 \sqrt{3} f_{r} Q}{\pi \sqrt{\pi} a b_{2} c} \exp \left(-\frac{3 x^{2}}{b_{2}^{2}}-\frac{3 y^{2}}{a^{2}}-\frac{3 z^{2}}{c^{2}}\right) & x<0\end{cases}
$$

where $q(x, y, z)$ is heat flow density in double ellipsoidal Gauss body of workpiece with its unit of $\mathrm{W} / \mathrm{m}^{2}$. $Q$ is effective power of arc provided by the welding power source with unit of $W f_{f}$ and $f_{r}$ are energy distribution coefficients of first and latter half of the model, which satisfy the relations: $f_{f}+f_{r}=2 . b_{1}, b_{2}$, $a$ and $c$ are the intercept of heat source flow field on axis of $x, y$ and $z$, which represents shape of the ellipsoid.

Heat flow density of each node was calculated out according to the given welding parameters and double ellipsoidal heat source distribution functions, and exerted on the chosen node. In the twin-arc submerged arc welding, two arc heat sources were obtained according to the given welding parameters and expression (5), then the two heat sources were exerted following the spatial distribution of the actual location of the arc, repeatedly doing this to the new nodes along the welding seam when arc center moving, and realize exertion of the two moving heat sources.

\section{Modeling Results and Discussions}

APDL (ANSYS parametric design language) of was employed to achieve pre-treatment, loading and boundary conditions of the workpiece, linear search and automatic time step were used to improve the computing accuracy and treatment of element birth and death, and Full New-
ton-Raphson method was used to solution. The parameters of twin-arc submerged arc welding were given in Table 1, the computing results were shown in Figure 3. Curve in Figure 3 were outline of weld pool that indicates the melting temperature of steel Q235. It was similar to the pool surface size from of low carbon steel from the practical testing.

In Figure 3, it can be found that outline of weld pool presents a former-small and later-large double-oval shape along the welding direction on the surface $(X-Y)$ and section $(Y-Z)$, this was because the effection of the second heat source to the first that leads to be wider at the end of the first heat source, and have a great deepen penetration, which indicates the twice heating process of base metal.

Geometric parameters presented the weld pool geometry mainly including: Maximum width of weld pool $B_{\max }$, weld pool length $L$, weld pool depth $H$. Maximum width of weld pool $B_{\max }$ was defined as maximum distance between two weld pool boundary points perpendicular to the welding direction. Weld pool length $L$ was defined as the distance between the head and tail of the weld pool. Weld pool depth $H$ was defined as maximum distance between two weld pool boundary points parallel to the welding direction. It can be seen from Figure 3 that the max weld width and penetration were in different sections, the max penetration was behind of the max width, the distance was supposed as $X$. The welding speed was supposed as $V_{B}$, the melting speed along the pool depth direction was $V_{H}$, arc heating effecting time in the max penetration was $t$, then $D=V_{H} \times t$. Welding speed was constant, the $X$ was expressed by

Table 1. Calculation conditions.

\begin{tabular}{ccccccc}
\hline $\begin{array}{c}\text { Welding } \\
\text { current (A) }\end{array}$ & $\begin{array}{c}\text { Welding } \\
\text { voltage }(\mathrm{V})\end{array}$ & $\begin{array}{c}\text { Wire } \\
\text { spacing }(\mathrm{mm})\end{array}$ & $\begin{array}{c}\text { Welding } \\
\text { speed }(\mathrm{m} / \mathrm{min})\end{array}$ & $\begin{array}{c}\text { Thermal } \\
\text { efficiency } \eta\end{array}$ \\
\hline$I_{\mathrm{f} 1}$ & $I_{\mathrm{f} 2}$ & $U_{\mathrm{f} 1}$ & $U_{\mathrm{f} 2}$ & 30 & 0.96 & 0.75 \\
\hline 700 & 600 & 36 & 38 & & & 0.96 \\
\hline
\end{tabular}
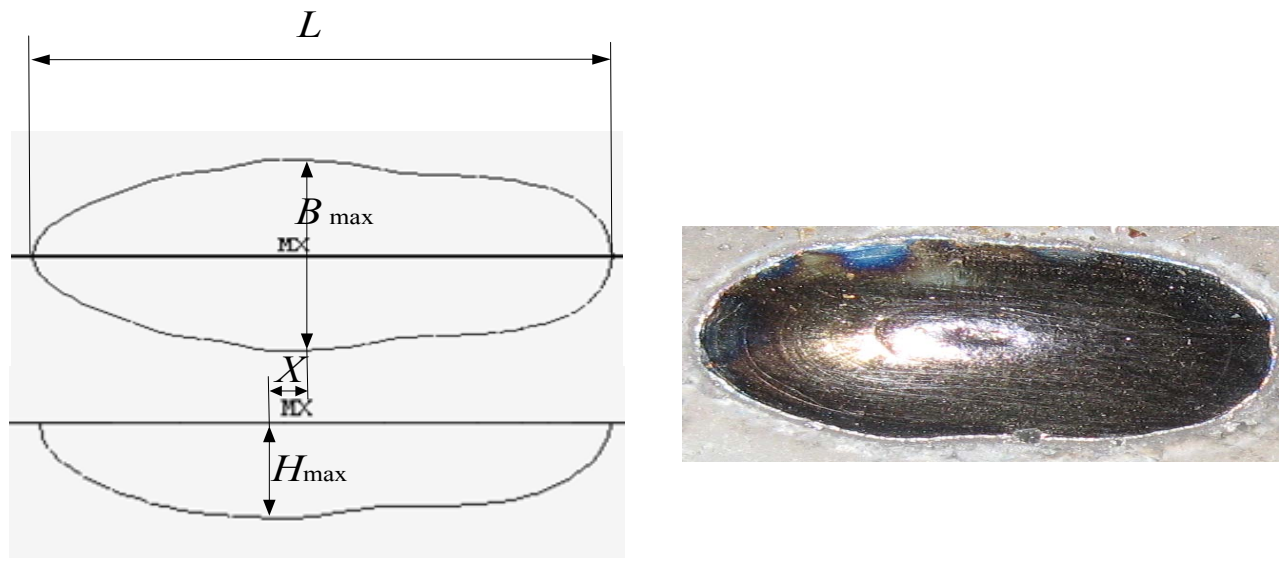

Figure 3. Calculated outline and practical surface of weld pool. 


$$
X=V_{B} \times t=V_{B} \times \frac{D}{V_{H}}=\frac{V_{B}}{V_{H}} \times D
$$

It can be seen from the expression that $X$ was proportional to the welding speed $V_{B}$, and inversely proportional to the melting speed $V_{H}$ along the pool depth direction. The larger the welding speed $V_{B}$ was, the greater the distance $X$ was. In high speed welding process, $X$ have a significant impact on weld pool behavior when $V_{B}$ was larger, which makes it difficult to guarantee welding quality, and also leads to phenomenon of undercut and hump weld seam.

In order to describe the influence rules of the weld pool behavior of high-speed welding on weld seam forming, Ratio of width to length of weld pool was introduced, and expressed as $\phi$, which was the ratio of the max weld width and weld pool length, the max weld width was expressed as $B$, the weld pool length was expressed as $L$, then the $\phi$ can be expressed by

$$
\phi=B / L
$$

The purpose of definition of these dimension parameters was to further analyze the influencing factors of weld pool behavior of twin-arc high speed submerged arc welding.

\section{Discussions}

\subsection{Effect of Welding Speed on Weld Pool Shape}

States of weld pool shape in single-arc and twin-arc welding when welding speed change were computed according to the parameters in Table 2 and Table 3, the results shows in Table 4.

Table 2. Calculation conditions.

\begin{tabular}{cccccc}
\hline $\begin{array}{c}\text { Welding } \\
\text { current } \\
(\mathrm{A})\end{array}$ & $\begin{array}{c}\text { Welding } \\
\text { voltage } \\
(\mathrm{V})\end{array}$ & $\begin{array}{c}\text { Wire } \\
\text { diameter } \\
(\mathrm{mm})\end{array}$ & $\begin{array}{c}\text { Plate } \\
\text { thickness } \\
(\mathrm{mm})\end{array}$ & $\begin{array}{c}\text { Plate } \\
\text { width } \\
(\mathrm{mm})\end{array}$ & $\begin{array}{c}\text { Welding } \\
\text { speed } \\
(\mathrm{m} / \mathrm{min})\end{array}$ \\
\hline 600 & 36 & 4 & 12 & 100 & $0.48 / 0.6 / 0.72$ \\
\hline
\end{tabular}

\begin{tabular}{|c|c|c|c|c|c|c|c|}
\hline \multicolumn{2}{|c|}{$\begin{array}{l}\text { Welding } \\
\text { current } \\
\text { (A) }\end{array}$} & \multicolumn{2}{|c|}{$\begin{array}{l}\text { Welding } \\
\text { voltage } \\
\text { (V) }\end{array}$} & \multirow{3}{*}{$\begin{array}{c}\begin{array}{c}\text { Wire } \\
\text { diameter } \\
(\mathrm{mm})\end{array} \\
4\end{array}$} & \multirow{3}{*}{$\begin{array}{c}\begin{array}{c}\text { Plate } \\
\text { thickness } \\
(\mathrm{mm})\end{array} \\
12\end{array}$} & \multirow{3}{*}{$\begin{array}{c}\begin{array}{c}\text { Wire } \\
\text { spacing } \\
(\mathrm{mm})\end{array} \\
30\end{array}$} & \multirow{3}{*}{$\begin{array}{c}\begin{array}{c}\text { Welding } \\
\text { speed } \\
(\mathrm{m} / \mathrm{min})\end{array} \\
0.96 / 1.2 / 1.44\end{array}$} \\
\hline$I_{\mathrm{f} 1}$ & $I_{\mathrm{f} 2}$ & $U_{\mathrm{f} 1}$ & $U_{\mathrm{f} 2}$ & & & & \\
\hline 600 & 600 & 36 & 38 & & & & \\
\hline
\end{tabular}

Table 3. Calculation conditions.

Table 4. Calculation results.

\begin{tabular}{ccccccc}
\hline Arc state & \multicolumn{3}{c}{ Single arc } & \multicolumn{3}{c}{ Double arc } \\
\hline $\begin{array}{c}\text { Welding speed } \\
(\mathrm{m} / \mathrm{min})\end{array}$ & 0.48 & 0.6 & 0.72 & 0.96 & 1.2 & 1.44 \\
$\begin{array}{c}\text { Weld width (mm) } \\
\text { Weld pool } \\
\text { length (mm) } \\
\begin{array}{c}\text { Ratio of width } \\
\text { to length }\end{array}\end{array}$ & 16.70 & 14.90 & 13.70 & 17.20 & 15.60 & 14.20 \\
\hline
\end{tabular}

It can be known from Table 4 that the weld width decreased while weld pool length increased and the ratio of width to length of the weld pool decreased gradually with the increase of welding speed. The ratio of width to length the weld pool in twin-arc welding was approximately equal to that of the single arc welding. As a result, the maximum Ratio of width to length was employed in this paper to analyze the effect of weld pool stability on weld seam forming in high speed welding process.

According to the above calculation and analysis, the twin-arc was arranged along the direction of welding, a weld pool was formed, detention time of the arc was lengthened, the critical welding speed of poor weld producing was effectively improved, tendency of production of poor weld seam was reduced. Meanwhile, owing to the mutual thermal effect of the twin-arc, heat energy efficiency and filling capacity of weld wire were increased, and also had a retarding effect on generation of hump in high speed submerged arc welding.

\subsection{Effect of Voltage on Weld Pool}

According to the parameters in Table 5, temperature distribution on the weld pool surface of twin-arc submerged arc welding in different arc voltage were computed, the results were shown in Table 5 and Figure 4 . It can be seen from the results that a former small and later large superimposed double-oval shape was presented with its axis along the welding direction on the $Y-Z$ surface, because the twice heating effect of the heat source lead to a deeper penetration at the beginning of the second heat source, it indicated the twice heating process of base metal. On the $X-Y$ surface of weld pool, when the voltage of the front arc was larger than that of the later arc, the center of weld pool surface was tightened, this kind of weld shape characteristic in high speed welding easily

Table 5. Calculation condition sand results.

\begin{tabular}{ccccccc}
\hline $\begin{array}{c}\text { sequence } \\
\text { number }\end{array}$ & $I_{\mathrm{f} 1}(\mathrm{~A})$ & $I_{\mathrm{f} 2}(\mathrm{~A})$ & $U_{\mathrm{f} 1}(\mathrm{~V})$ & $U_{\mathrm{f} 2}(\mathrm{~V})$ & $\begin{array}{c}\text { Welding } \\
\text { speed } \\
(\mathrm{m} / \mathrm{min})\end{array}$ & $\begin{array}{c}\text { Breadth } \\
\text { length } \\
\text { ratio }\end{array}$ \\
\hline (a) & 600 & 600 & 38 & 36 & 0.6 & 0.36 \\
(b) & 600 & 600 & 36 & 38 & 0.6 & 0.38 \\
\hline
\end{tabular}

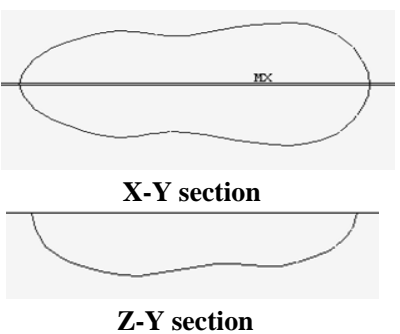

(a)

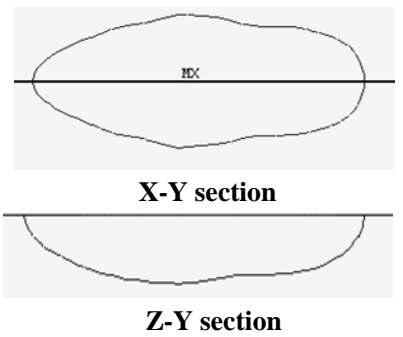

(b)
Figure 4. Weld pool contour of different voltage combination. 
lead to generation of weld defects such biting edge and the hump. When the voltage of the front arc was smaller than that of the later arc, a former-small and later-large superimposed double-oval shape was presented with its axis along the welding direction on the $X-Y$ surface, which indicated the twice heating process of base metal, and the calculated results of the ratio of width to length was lager than the former. Conclusions can be obtained that weld defects such as hump can be partly resisted when the voltage of the front arc was slightly less than that of the later arc along the welding direction, and perfect weld seam performance can be obtained.

\subsection{Effect of Current on Weld Pool}

The size and collocation of the twin-arc current were most important to the temperature field distribution of weld pool. The front and later arc voltage were selected as $36 \mathrm{~V}$ and $38 \mathrm{~V}$ respectively, the total inputting current was $1300 \mathrm{~A}$, temperature field distribution of weld pool was calculated according to the parameters in Table 6, the calculated results were shown in Figure 5.

It can be seen from the calculated results, when the current ratio of the front and later arc $I_{\mathrm{f} 1}: I_{\mathrm{f} 2}$ changed from $1: 1$ to $7: 6$, the ratio of width to length was relative large. Conclusions can be obtained that weld defects such as hump can be partly resisted when the heat inputting of the front arc was slightly larger than that of the later arc along the welding direction, and perfect weld seam performance can be obtained.

Table 6. Calculation conditions.

\begin{tabular}{ccccc}
\hline $\begin{array}{c}\text { Welding } \\
\text { speed } \\
(\mathrm{m} / \mathrm{min})\end{array}$ & $\begin{array}{c}\text { Wire } \\
\text { diameter } \\
(\mathrm{mm})\end{array}$ & $\begin{array}{c}\text { Plate } \\
\text { thickness } \\
(\mathrm{mm})\end{array}$ & $\begin{array}{c}\text { Plate } \\
\text { width } \\
(\mathrm{mm})\end{array}$ & $\begin{array}{c}\text { Current ratio } \\
I_{\mathrm{f} 1}: I_{\mathrm{f} 2}\end{array}$ \\
\hline 0.96 & 4 & 12 & 100 & $2: 8 / 3: 7 / 4: 6 / 1: 1 / 6: 4 / 7: 3 / 8: 2$ \\
\hline
\end{tabular}

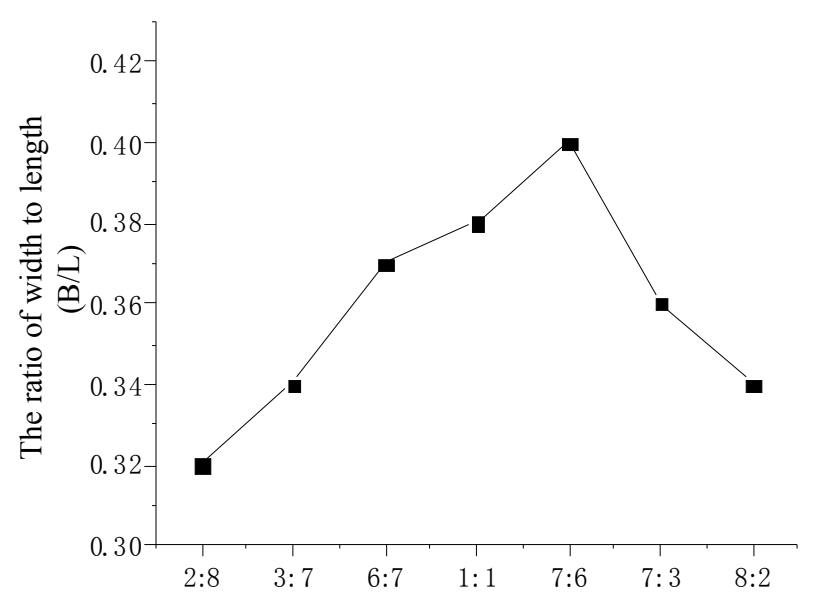

Figure 5. The ratio of width and length of weld pool in different current of two arc.

\subsection{Effect of Different Wire Space on Weld Pool}

The space of twin-arc effect on the shape of weld pool was obvious. If the space between the two wires was zero, its effect was equivalent to the work of a single arc, this was an ideal state. If distance was too large, two weld pools will be formed and independently of each other. According to the parameters in Table 7, the calculated results are shown in Table 8. It can be seen that the ratio of width to length of weld pool reduced gradually with the increasing of space between the two wires.

In order to get the ratio of width to length of the weld pool and ensure the weld seam performance, space between the two wires should be closer. If the space between the two wires was too closer, because the interaction was existed in the twin-arc, it made large interfereence and reduced the arc stability. As a result of this, the arc stability and effect factors on the weld shaping should be considered in practice.

\section{Conclusions}

Temperature field finite element numerical simulation model of twin arc movement was established. The loading form of twin-arc with double ellipsoid heat source was realized by the APDL of ANSYS. The three-dimensional dynamic simulation of temperature field of plate submerged arc resurfacing welding was conducted. The geometric parameters of weld pool were obtained through calculation data results. The effect rules of welding process on the morphological character of weld pool were analyzed by introducing the ratio of width to length proposed in this paper. Numerical simulation of twin-arc submerged arc welding indicated the law of molten pool variation and weld formation as following. With increaseing of the welding speed, the welding width decreased and the pool length increased gradually, the ratio of width to length of weld pool reduced gradually, it would raise the generation tendency of poor weld shaping. When the two heat sources was arrayed in tandem along the welding direction, the ratio of width to length of weld pool could

Table 7. Calculation conditions.

\begin{tabular}{ccccccc}
\hline $\begin{array}{c}\text { Welding } \\
\text { current (A) }\end{array}$ & $\begin{array}{c}\text { Welding } \\
\text { voltage }(\mathrm{V})\end{array}$ & $\begin{array}{c}\text { Wire } \\
\text { diameter } \\
(\mathrm{mm})\end{array}$ & $\begin{array}{c}\text { Welding } \\
\text { speed } \\
(\mathrm{m} / \mathrm{min})\end{array}$ & $\begin{array}{c}\text { Wire } \\
\text { Space } \\
(\mathrm{mm})\end{array}$ \\
\hline$I_{\mathrm{f} 1}$ & $I_{\mathrm{f} 2}$ & $U_{\mathrm{f} 1}$ & $U_{\mathrm{f} 2}$ & 4 & 0.96 & $\begin{array}{c}30 / 40 / \\
50 / 60\end{array}$ \\
\hline 600 & 500 & 36 & 38 & & &
\end{tabular}

Table 8. Calculation results.

\begin{tabular}{ccccc}
\hline Wire spacing $l(\mathrm{~mm})$ & 30 & 40 & 50 & 60 \\
Weld width $(\mathrm{mm})$ & 17.20 & 16.23 & 15.91 & 14.44 \\
Pool length $(\mathrm{mm})$ & 43.70 & 54.8 & 65.71 & 76.82 \\
Breadth length ratio & 0.400 & 0.300 & 0.242 & 0.188 \\
\hline
\end{tabular}


be effectively increased, poor weld shaping was restrained and higher speed welding was realized.

\section{Acknowledgements}

Project supported by Hunan Provincial Natural Science Foundation of China (11JJ2027), National Natural Science Foundation of China (51005073), Project of Hunan Provincial Research Scheme (2011GK3052), Scientific Research Fund of Hunan Provincial Education Department (10C0682), Ph. D Start Fund (E51088), CEEUSRO special plan of Hunan province (2010XK6066), Industrial Cultivation Program of Scientific and Technological Achievements in Higher Educational Institutions of $\mathrm{Hu}-$ nan Province (10CY008), also from Aid program for Science and Technology Innovative Research Team in Higher Educational Institutions of Hunan Province, are gratefully acknowledged.

\section{REFERENCES}

[1] D. J. Tusek, "Mathematical Modeling of Melting Rate in Twin-Wire Welding," Journal of Materials Processing Technology, Vol. 100, No. 1-3, 2000, pp. 250-256. doi:10.1016/S0924-0136(99)00485-9

[2] H. Q. Li, X. Wang and X. P. Cai, "Developing Status of SAW at Home and Abroad," Electric Welding Machine, Vol. 36, No. 4, 2006, pp. 1-6.

[3] J. Dong, C. L. Mo and Q. C. Shan, "The Simulation of the Automatic Welding Temperature Field in the Hidden Arc Butt Joint Welding of 20 Steel Tube," Transactions of Shenyang Ligong University, Vol. 26, No. 2, 2007, pp. $38-41$.

[4] X. F. Tan and H. Zhang, "Analysis of Temperature and Stress Fields in Welding Process by Thermo-Elastoplastic Finite Element Method," Journal of Plasticity Engineering, Vol. 11, No. 5, 2004, pp. 71-74.

[5] C. L. Mo, B. N. Qian and X. M. Guo, "The Development of Models about Welding Heat Sources Calculation," Transactions of the China Welding Institution, Vol. 22, No. 3, 2001, pp. 93-96.

[6] W. F. Zhu, Z. Q. Lin and X. M. Lai, "Numerical Analysis of Projection Welding on Auto-Body Sheet Metal Using a Coupled Finite Element Method," The International Journal of Advanced Manufacturing Technology, Vol. 28, No. 1-2, 2006, pp. 45-52. doi:10.1007/s00170-004-2336-8

[7] Z, Paley and P. D. Nbbrt, "Computation of Temperatures in Actual Weld Designs," Welding Journal, Vol. 54 , No. 11, 1975, pp. 385-392.

[8] T. W. Eager and N. S .Tsai, "Temperature Fields Produced by Traveling Distributed Heat Sources," Welding Journal, Vol. 62, No. 12, 1983, pp. 346-355.
[9] G. A. John, "A New Finite Model for Welding Hear Source," Metallurgical Transactions, Vol. 15, No. 2, 1984, pp. 299-305. doi:10.1007/BF02667333

[10] Q. G. Meng, "Heat Source Model For Twin Wire Welding," Chinese Journal of Mechanical Engineering, Vol. 41, No. 4, 2005, pp. 110-113. doi:10.3901/JME.2005.04.110

[11] H. B. Dong, H. K. Chul and Y. C. Seon, "Numerical Analysis of Welding Residual Stress Using Heat Source Models for the Multi-Pass Weldment," Korean Society of Mechanical Engineers International Journal, Vol. 16, No. 9, 2002, pp. 1054-1064.

[12] Z. G. Gao, Y. X. Wu and J. Huang, "Analysis of Weld Pool Dynamic during Stationary Laser-MIG Hybrid Welding," The International Journal of Advanced Manufacturing Technology, Vol. 44, No. 9-10, 2009, pp. 870879. doi:10.1007/s00170-008-1896-4

[13] M. Zhao and R. Y. Li, "Numerical Analysis of Dynamic Variation of Weld Pool Geometry in Fully-Penetrated TIG Welding," China Welding, Vol. 17, No. 2, 2008, pp. 47-53.

[14] S. L Chen, Z. S. Wu and C. R. Liu, "Numerical Simulation of Temperature Field in Deep Penetration Laser Welding of 5A06 Aluminum Cylinder," China Welding, Vol. 17, No. 4, 2008, pp. 74-78.

[15] H. J. Aval, A. Farzadi and S. Serajzadeh, "Theoretical and Experimental Study of Microstructures and Weld Pool Geometry during GTAW of 304 Stainless Steel," The International Journal of Advanced Manufacturing Technology, Vol. 42, No. 11-12, 2009, pp. 1043-1051. doi:10.1007/s00170-008-1663-6

[16] Z. Q. Lin, Y. B. Li and Y. S. Wang, "Numerical Analysis of a Moving Gas Tungsten Arc Weld Pool with an External Longitudinal Magnetic Field Applied," The International Journal of Advanced Manufacturing Technology, Vol. 27, No. 3-4, 2005, pp. 288-295.

doi:10.1007/s00170-004-2194-4

[17] W. F. Zhu, Z. Q. Lin and X. M. Lai, "Numerical Analysis of Projection Welding on Auto-Body Sheet Metal Using a Coupled Finite Element Method," The International Journal of Advanced Manufacturing Technology, Vol. 28, No. 1-2, 2006, pp. 45-52. doi:10.1007/s00170-004-2336-8

[18] K. F. He, X. J. Li and J. G. Wu, "Three-Dimensional Temperature Field Numerical Simulation of Twin-Arc," Advanced Materials Research, Vol. 216, 2011, pp. 188193. doi:10.4028/www.scientific.net/AMR.216.188

[19] S. L. Huang, Y Xue and J. X. Zhang, "3D Finite Element Simulation on Stress-Strain Distributions in All Position Root Butt Welding of Pipe," Transactions of the China Welding Institution, Vol. 27, No. 4, 2006, pp. 73-75.

[20] H. N. Cai and M. Y. Tang, "FEM Analysis on TIG Welding Temperature Field," Chinese Journal of Mechanical Engineering, Vol. 32, No. 2, 1996, pp. 34-39. 